\title{
Inter-laboratory Pressure Comparison Measurement In Gas Medium at \pm 150 hPa Range
}

\author{
Yasin Durgut ${ }^{1 *}$, Recep Yilmaz ${ }^{2}$ and Abdullah Hamarat ${ }^{3}$ \\ 1* TUBITAK National Metrology Institute (TUBITAK UME), Turkey, Kocaeli, Turkey, (ORCID ID 0000-0001-8901-4166), yasin.durgut@tubitak.gov.tr \\ 2 TUBITAK National Metrology Institute (TUBITAK UME), Turkey, Kocaeli, Turkey, (ORCID ID 0000-0002-0538-8011), yilmaz.recep@tubitak.gov.tr \\ ${ }^{3}$ TUBITAK National Metrology Institute (TUBITAK UME), Turkey, Kocaeli, Turkey, (ORCID ID 0000-0003-1324-7750), abdullah.hamarat@tubitak.gov.tr
}

(1st International Conference on Applied Engineering and Natural Sciences ICAENS 2021, November 1-3, 2021)

(DOI: 10.31590/ejosat.1001930)

ATIF/REFERENCE: Durgut, Y., Yilmaz, R. \& Hamarat, A. (2021). Inter-laboratory Pressure Comparison Measurement In Gas Medium at $\pm 150 \mathrm{hPa}$ Range. European Journal of Science and Technology, (28), 391-394.

\begin{abstract}
Results of interlaboratory comparisons and proficiency tests are a significant parameter for the calibration and testing laboratories for assuring the quality of test and calibration results performed by those laboratories. Accredited and non-accredited laboratories that have a quality system for their working areas are expected to join into inter-comparisons and proficiency tests in certain periods to show a degree of equivalence among the participant laboratories and assure their service quality. The necessity of participating in comparison measurements (ILC) and proficiency tests (PT) are stated in the EN ISO/IEC 17025:2017 International Standard that accredited laboratories or laboratories applying for accreditation must participate in ILC and PT from parameters related to measurement quantities within the scope of accreditation and have achieved successful results, and it is also a requirement sought by accreditation bodies.

This study gives the organisation steps and the obtained results of a bilateral pressure comparison measurement of digital pressure gauge in the hydraulic medium between UME and an accredited laboratory in industry between $\pm 150 \mathrm{hPa}$.
\end{abstract}

Keywords: Pressure, comparison, calibration, ISO17025, uncertainty, degree of equivalence.

\section{\pm 150 hPa Gas Ortamda Laboratuvarlararası Basınç Karşılaştırması}

$\ddot{O} z$

Laboratuvarlar arası karşılaştırmalar ve yeterlilik testleri sonuçları, kalibrasyon ve test laboratuvarları için, bu laboratuvarlar tarafından gerçekleştirilen test ve kalibrasyon sonuçlarının kalitesini güvence altına almak için önemli bir parametredir. Çalışma alanları için kalite sistemi olan akredite ve akredite olmayan laboratuvarların, katılımcı laboratuvarlar arasında bir dereceye kadar eşdeğerlik göstermek ve hizmet kalitesini güvence altına almak için belirli periyotlarda karşılıklı karşılaştırma ve yeterlilik testlerine katılması beklenmektedir. Karşılaştırmalı ölçümlere (ILC) ve yeterlilik testlerine (PT) katılmanın gerekliliği EN ISO/IEC 17025:2017 Uluslararası Standardında, akredite laboratuvarların veya akreditasyon başvurusunda bulunan laboratuvarların, bünyesinde yer alan ölçüm miktarlarıyla ilgili parametrelerden ILC ve PT'ye katılması gerektiği belirtilmiştir.

Bu çalışma, UME ile endüstride akredite bir laboratuvar arasında $\pm 150 \mathrm{hPa}$ arasında hidrolik ortamdaki dijital basınç ölçerin ikili basınç karşılaştırma ölçümünün organizasyon adımlarını ve elde edilen sonuçlarını vermektedir.

Anahtar Kelimeler: Basınç, Karşılaştırma, Kalibrasyon, ISO 17025, Belirsizlik, Denklik derecesi. 


\section{Introduction}

Measurement underpins a wide range of socio-economic activities, both domestic and international. The global market needs accurate and reliable measurements so that technical trade barriers can be minimized. In all sectors, the need for reliable measurement results that can be compared across space and time has never been greater. Reliable measurements depend critically on competent staff, validated and tested methods, comprehensive quality systems, and traceability to appropriate measurement references. Recognition of these requirements is underscored by the increasing adoption of standards and measurement quality systems, such as laboratory accreditation against EN ISO/IEC 17025:2017 (BS EN ISO/IEC 17025:2017). Inter-laboratory comparison measurements are an important parameter for the calibration/experimental laboratories' activities to ensure the test/calibration quality. Laboratories that offer their services within a quality system, especially laboratories that have received accreditation certificates, are expected to participate in multiple inter-laboratory comparisons, if possible, to demonstrate the service quality. ISO/IEC 17025:2017 General requirements for the competence of testing and calibration laboratories (BS EN ISO/IEC 17025:2017) standard specifies the general requirements for the competence, impartiality and consistent operation of laboratories. This standard applies to all organizations performing laboratory activities, regardless of the number of personnel. Laboratory customers, regulatory authorities, organizations and schemes using peer-assessment, accreditation bodies, and others use ISO/IEC 17025:2017 in confirming or recognizing the competence of laboratories.

It is stated in the ISO/IEC 17025:2017 that accredited laboratories or laboratories applying for accreditation must participate in inter-laboratory comparisons (ILC) from parameters related to measurement quantities within the scope of accreditation and have achieved successful results, and it is also a requirement sought by the Turkish Accreditation Agency TURKAK.

Proficiency testing involves the use of interlaboratory comparisons for the determination of laboratory performance. ISO/IEC 17043:2010 Conformity assessment - General requirements for proficiency testing (ISO/IEC 17043:2010) standard specifies general requirements for the competence of providers of proficiency testing schemes and the development and operation of proficiency testing schemes.

\section{Material and Method}

To respond to ILC need, a bilateral ILC measurement was organised and piloted by TUBITAK UME (National Metrology Institute of Turkey). The measurement result values of the UME, in other words, the measurement result values of the pilot laboratory, were taken as reference values for ILC. This situation is stated in the measurement technical protocol document, which was prepared and approved jointly by all participants before the start of ILC. In addition, this approved technical protocol includes all information such as how the ILC will be performed, who will attend, which test instrument or transfer standard (TS) will be used in the measurements, how and when the results will be sent to the pilot laboratory, how the results will be analyzed and how the final report will be prepared.
In ILC a pneumatic digital pressure gauge (TS) device was used with the pressure range of $\pm 150 \mathrm{hPa}$. ILC measurements were made by star type measurement method. Firstly, the initial measurement was performed by the pilot laboratory and TS was sent to the participant. After the participant laboratory completed its measurement, the TS was delivered to the pilot laboratory back. The pilot laboratory repeated the measurement with TS based on the technical protocol. The transportation of the TS was performed by a courier company. All measurements were done according to the ILC measurement schedule as agreed in the technical protocol (EURAMET Project 1131, 2009 EURAMET Project 1131, 2012). The star type method allowed us to determine the possible drifts between measurements if available during the ILC schedule.

Participating laboratory requested to perform its measurements with its available measurement system and measurement method and with his best measurement uncertainties declared or will be declared within the scope of accreditation. The data obtained as a result of the participant laboratory asked to send pilot for analysing.

Specifications of transfer standard (TS) that was used in interlaboratory comparison (ILC) measurements and ILC pressure points were given in Table 1. The TS was given in Fig. 1

Table 1. Transfer standard and measurement points

\begin{tabular}{|c|c|}
\hline Transfer Standard & Digital pressure gauge \\
\hline Measurement Range & $\pm 150 \mathrm{hPa}$ \\
\hline Manufacturer & Rothenberger \\
\hline Type & EM200 \\
\hline $\begin{array}{c}\text { Serial Number } \\
\text { Basınç Ortamı }\end{array}$ & Pneumatic (gas) \\
\hline $\begin{array}{c}\text { Measurement points } \\
(\mathrm{hPa})\end{array}$ & $\begin{array}{r}-15,-50,-75,-100,-150,15,50, \\
75,100,150\end{array}$ \\
\hline
\end{tabular}

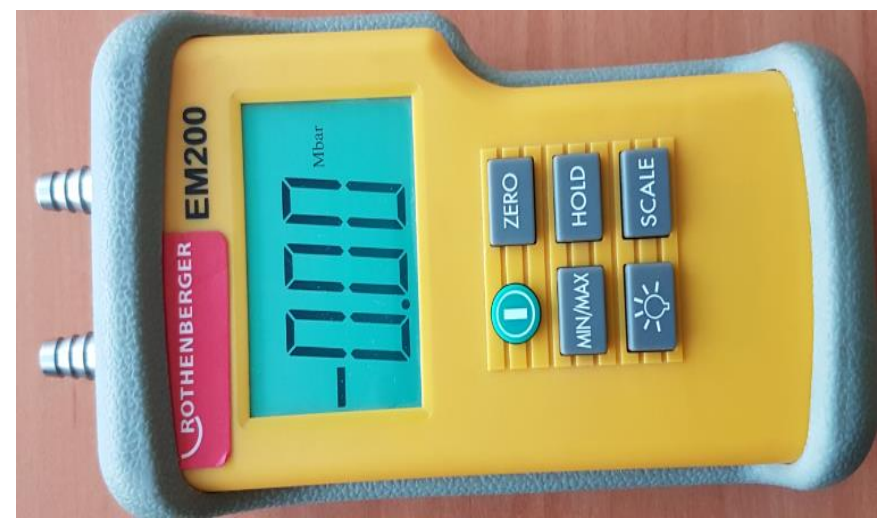

Fig.1 Transfer standard (TS) 


\section{Results and Discussion}

Measurement results for participant laboratory at $150 \mathrm{hPa}$ were given in Table 2.

Table 2. Results for participant laboratory at $150 \mathrm{hPa}$

\begin{tabular}{|c|c|c|c|c|}
\hline \multirow{2}{*}{$\begin{array}{c}\text { Nominal } \\
\text { pressure }\end{array}$} & \multicolumn{2}{|l|}{ Increasing direction } & \multicolumn{2}{c|}{ Decreasing direction } \\
\cline { 2 - 5 } & Error & $\mathbf{U}(\mathbf{k}=\mathbf{2})$ & Error & $\mathbf{U}$ (k=2) \\
\hline $\mathrm{hPa}$ & $\mathrm{hPa}$ & $\mathrm{hPa}$ & $\mathrm{hPa}$ & $\mathrm{hPa}$ \\
\hline 15 & 0.6 & 0.3 & 0.6 & 0.3 \\
\hline 50 & 0.3 & 0.2 & 0.2 & 0.2 \\
\hline 75 & 0.5 & 0.3 & 0.4 & 0.3 \\
\hline 100 & 0.1 & 0.8 & 0.1 & 0.8 \\
\hline 150 & 0.1 & 0.8 & 0.1 & 0.8 \\
\hline
\end{tabular}

Measurement results for participant laboratory at $-150 \mathrm{hPa}$ were given in Table 3.

\section{Table 3. Results for participant laboratory at $-150 \mathrm{hPa}$}

\begin{tabular}{|c|c|c|c|c|}
\hline \multirow{2}{*}{$\begin{array}{c}\text { Nominal } \\
\text { pressure }\end{array}$} & \multicolumn{2}{|c|}{ Increasing direction } & \multicolumn{2}{c|}{ Decreasing direction } \\
\cline { 2 - 5 } & Error & $\mathbf{U}(\mathbf{k}=\mathbf{2})$ & Error & $\mathbf{U}(\mathbf{k}=\mathbf{2})$ \\
\hline $\mathrm{hPa}$ & $\mathrm{hPa}$ & $\mathrm{hPa}$ & $\mathrm{hPa}$ & $\mathrm{hPa}$ \\
\hline-15 & -0.1 & 0.3 & -0.1 & 0.3 \\
\hline-50 & -0.4 & 0.2 & -0.4 & 0.2 \\
\hline-75 & -0.7 & 0.2 & -0.6 & 0.2 \\
\hline-100 & -0.5 & 0.9 & -0.5 & 0.9 \\
\hline-150 & -0.3 & 0.8 & -0.3 & 0.8 \\
\hline
\end{tabular}

Results for the pilot laboratory were considered as reference values in the ILC. Reference values were provided in Table 4. and Table 5 .

Table 4. Reference values up to $150 \mathrm{hPa}$

\begin{tabular}{|c|c|c|c|c|}
\hline \multirow{2}{*}{$\begin{array}{c}\text { Nominal } \\
\text { pressure }\end{array}$} & \multicolumn{2}{|c|}{ Increasing direction } & \multicolumn{2}{c|}{ Decreasing direction } \\
\cline { 2 - 5 } & Error & $\mathbf{U ~ ( k = 2 )}$ & Error & $\mathbf{U ~ ( k = 2 )}$ \\
\hline $\mathrm{hPa}$ & $\mathrm{hPa}$ & $\mathrm{hPa}$ & $\mathrm{hPa}$ & $\mathrm{hPa}$ \\
\hline 15 & 0.5 & 0.2 & 0.6 & 0.2 \\
\hline 50 & 0.2 & 0.2 & 0.2 & 0.2 \\
\hline 75 & 0.4 & 0.2 & 0.4 & 0.2 \\
\hline 100 & 0.1 & 0.1 & 0.1 & 0.1 \\
\hline 150 & 0.1 & 0.1 & 0.1 & 0.1 \\
\hline
\end{tabular}

Table 5. Reference values up to $-150 \mathrm{hPa}$

\begin{tabular}{|c|c|c|c|c|}
\hline \multirow{2}{*}{$\begin{array}{c}\text { Nominal } \\
\text { pressure }\end{array}$} & \multicolumn{2}{|c|}{ Increasing direction } & \multicolumn{2}{c|}{ Decreasing direction } \\
\cline { 2 - 5 } & Error & $\mathbf{U ~ ( k = 2 )}$ & Error & $\mathbf{U}(\mathbf{k}=\mathbf{2})$ \\
\hline $\mathrm{hPa}$ & $\mathrm{hPa}$ & $\mathrm{hPa}$ & $\mathrm{hPa}$ & $\mathrm{hPa}$ \\
\hline-15 & 0 & 0.1 & 0 & 0.1 \\
\hline-50 & -0.3 & 0.2 & -0.2 & 0.2 \\
\hline-75 & -0.5 & 0.1 & -0.5 & 0.1 \\
\hline-100 & 0 & 0.1 & 0 & 0.1 \\
\hline-150 & 0 & 0.1 & 0 & 0.1 \\
\hline
\end{tabular}

To decide if the results of a participant laboratory are successful and satisfactory, the pre-defined criteria En values were calculated for each calibration point. This calculation is based on ISO/IEC GUIDE 43=1:1997(E). If the En value of the laboratory is in the range of -1 to +1 , the laboratory results are considered equivalent to the reference value. The declared expanded uncertainty value is the result of multiplying the standard uncertainty by the coverage factor $\mathrm{k}=2$, which gives approximately a $95 \%$ confidence level for the normal distribution. The En value was calculated using equation 1.

$E_{n}=\frac{X_{i}-X_{r e f}}{\sqrt{U_{(x i)}^{2}+U_{(x r e f)}^{2}}}$

(1) (ISO/IEC 17043:2010), 4]

where;

$E_{n}:$ Normalised error

$X_{i}:$ Error for participant laboratory

$X_{\text {ref }} \quad$ : Error for reference (pilot) laboratory

$U_{(x i)} \quad$ : Expanded uncertainty for participant laboratory

$U_{(x r e f)}:$ Expanded uncertainty for reference laboratory

En values were given in Table 6. The graph of En values of the accredited laboratory versus nominal pressure point is given in Fig 2.

Table 6. En values

\begin{tabular}{|c|c|c|}
\hline $\begin{array}{c}\text { Nominal } \\
\text { pressure } \\
\text { (hPa) }\end{array}$ & $\begin{array}{c}\text { Increasing } \\
\text { direction }\end{array}$ & $\begin{array}{c}\text { Decreasing } \\
\text { direction }\end{array}$ \\
\hline 15 & 0.27 & 0.11 \\
\hline 50 & 0.20 & 0.02 \\
\hline 75 & 0.24 & 0.07 \\
\hline 100 & 0.01 & 0.01 \\
\hline 150 & 0.05 & 0.04 \\
\hline
\end{tabular}

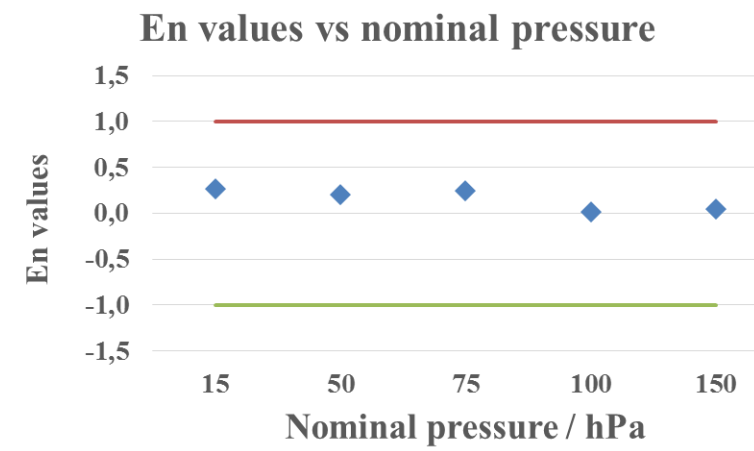

- Accredited Laboratory —En +1 upper limit — En -1 lower limit

Fig.2 Transfer standard (TS)

A bilateral ILC was organized between TUBITAK UME and an accredited laboratory at the range of $\pm 150 \mathrm{hPa}$ pneumatic pressure to provide a degree of equivalence for participating laboratory. The transfer standard was a digital pressure gauge manufactured by Rothenberger, which was circulated without major problems in 2019 between the participants.

The reference value of the comparison has been considered based on the results of the pilot laboratory (Y. Durgut, 2012). The 
stability of the transfer standard was analysed by measuring the TS by the pilot laboratory before and after the measurement of the participant during the comparison life cycle.

As a result of the evaluations and En results as given in Table 6. and in Fig. 1 it was concluded that the participant laboratory measurement results provided the equivalence degree with those of the pilot reference laboratory. In other words, the equivalence was realised between the results of the pilot laboratory and those of the participant laboratory. Participant laboratory has ensured the quality and equivalence of its results to be provided to the customer in its calibration certificates (1).

\section{Conclusions and Recommendations}

As a result of organized bilateral ILC between TUBITAK UME and the accredited laboratory at the range of $\pm 150 \mathrm{hPa}$ pneumatic pressure, the degree of equivalence was established successfully. It was proven that results for the participant laboratory were equal to the results for the pilot laboratory.

In addition, this ILC provided the participating laboratory with the opportunity to test and validate the reference device used in the ILC, the method is applied, and to evaluate the competence of the calibration operator who made the measurements. Besides, determine their necessities in terms of the technical employee, training, and improve measurement methods and measurement capabilities of the laboratory have other outcomes to participant laboratory.

\section{References}

BS EN ISO/IEC 17025:2017 General requirements for the competence of testing and calibration laboratories, ISBN 9780 53901414 3, The British Standards Institution, 2018

ISO/IEC 17043:2010 Conformity assessment - General requirements for proficiency testing, Edition:1, by Technical Committee ISO/CASCO on conformity assessment, 2010-02

EURAMET Project 1131, Negative gauge pressure comparison, MIKES, 2009

EURAMET Project 1197, Supplementary bilateral comparison of hydraulic gauge pressure standards up to $50 \mathrm{MPa}$, TÜBİTAK UME, 2012.

Y. Durgut, The Evaluation Of Interlaboratory Comparison In Hydraulic Pressure Region, XX IMEKO World Congress Metrology for Green Growth September 9-14, 2012, Busan, Republic of Korea 